\title{
DIRECT REDUCTION OF URANIUM HEXAFLUORIDE TO METALLIC URANIUM \\ By
}

D. E. CARPENTER, C. P. JOHNSTON,

C. D. SUSANO

\section{Y-12 PLANT \\ CARBIDE AND CARBON CHEMICALS CORPORATION OAK RIDGE, TENNESSEE}

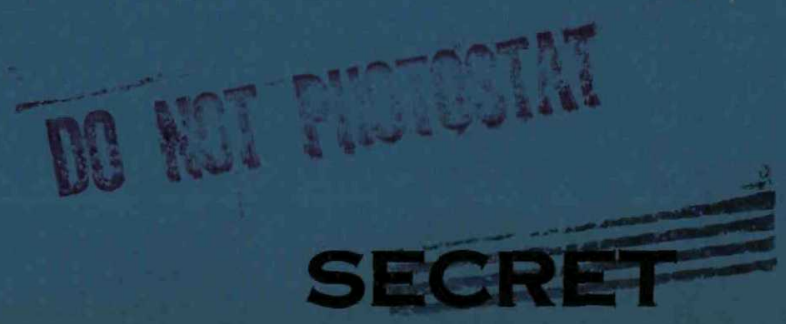




\section{DISCLAIMER}

This report was prepared as an account of work sponsored by an agency of the United States Government. Neither the United States Government nor any agency Thereof, nor any of their employees, makes any warranty, express or implied, or assumes any legal liability or responsibility for the accuracy, completeness, or usefulness of any information, apparatus, product, or process disclosed, or represents that its use would not infringe privately owned rights. Reference herein to any specific commercial product, process, or service by trade name, trademark, manufacturer, or otherwise does not necessarily constitute or imply its endorsement, recommendation, or favoring by the United States Government or any agency thereof. The views and opinions of authors expressed herein do not necessarily state or reflect those of the United States Government or any agency thereof. 


\section{DISCLAIMER}

Portions of this document may be illegible in electronic image products. Images are produced from the best available original document. 
Index No.

Y 400

Subject Catogorys lechnology。 Yoi2

CARBTDE AID CARBON GHERTCALS CORPORATION

Y-12 Flant

$W-7405-E n g-26$

RESERRCH AND DEVELOPAENT DIVISION

Dr. E. D. Shipley, Director

CHEMICAI DEVELOPUENT DEPARTENT

ui. G. H. Clenett, superintendent

DIRECT REDUCTION OF UKANIUY HEXAFLUORTDE

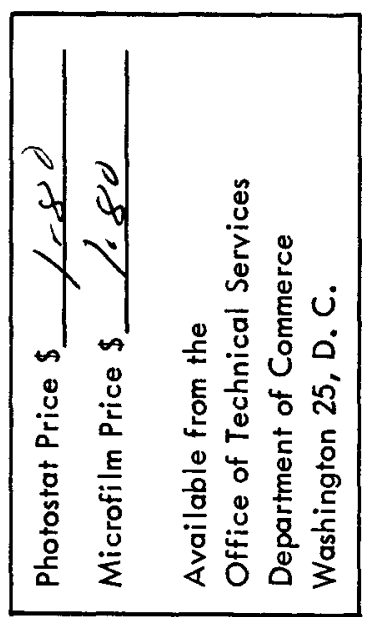

TO UETALLTC URANIUY

Abstract

Exploratory tests are reported which indicate the feasibility of a ono-step reduction process for the ureparation of uranium motal from the hexafluoride by the action of calcium motal and iodine.

D. E. Carponter

C. P. Johnston

C. D. Susano

Cak Ridge, Tennsssee

the lay 16, 1949 
Indox Hoo $Y-409$

Trahnology。 Yole

Distribution, Series A:

1028. Carbide and Carbon Chemicals Corporation (Yo12 Plant)

19-20. Atomic Fnergy Comission。 Washington

21. Patont Branch, 唡esington

22-27. Teohnical Information Branch, ORE

28-29. University of California Radiation Laboratory

Carbide and Carbon Chemicals Corporation ( $Y-12$ Plant) internal distribution as follows:

\begin{tabular}{|c|c|}
\hline $\begin{array}{l}30 \\
90 \\
100 \\
110 \\
120 \\
130 \\
34 . \\
150 \\
160 \\
17=38\end{array}$ & 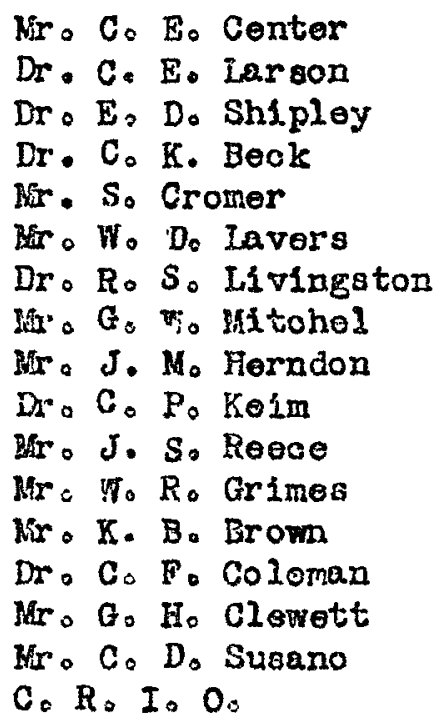 \\
\hline
\end{tabular}

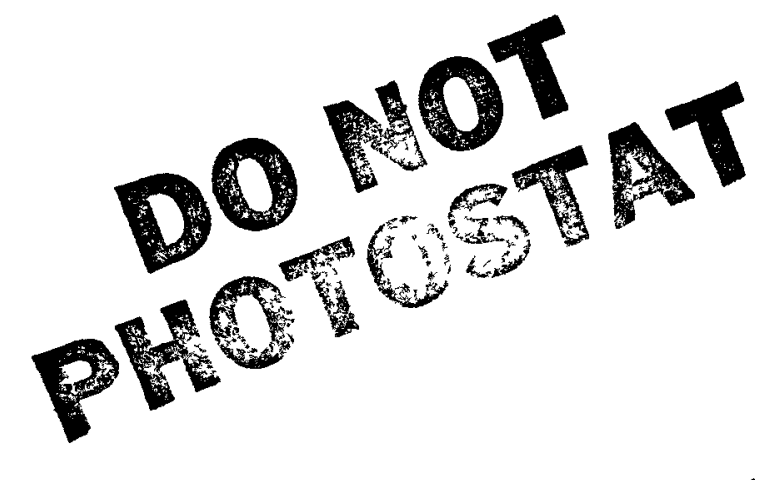

Contral Reports and Information offico

Date Issueds JUN 171949

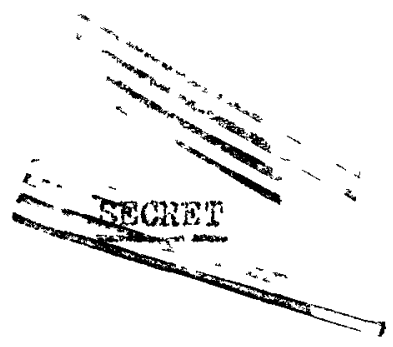




\section{三 \\ DIREG REDUCTION OF URANIUM HEXAS LUORIDE TO NETALITC URANIUH}

The reduction of uranium tetrafluoride by reaction with metallic calcium to produce metsllic uraniun and calcium fluoride has been known for some time, and accepted as standard procedure in the preparation of metallic uranium.

In case that it is desired to prepare uraniua metal from uranjum hexaflroride, as the raw material, the usual procedure is tc first convert the cranium hexafluoride to uranium totrafluoride by one of several established rethods, followed by calcium reduction to metallic uranium.

The purpose of the experiments reported here was to explore the possibilivies of a direct method of conversion from Uf 6 to metallic urainium, by reduction with metallic calcium, thus eliminating the usual step of converting the $\mathrm{UF}_{6}$ to $\mathrm{UF}_{4}$.

Two runs vere carrled out in which $\mathrm{UF}_{6}$ was reacted with metallic calcium to form metallic uranium, the experiments being carried out in a similar method and equipment to that ordinarily used in the preparation of metallic uranium from UF 4 .

In the first run, 19 grams of $\mathrm{UF}_{6}$, sealed in a glass bulb, along with a considerablo excess of reducing roactants, 30 grams of calcium and 3 grams of lodine were placed in an iron, cylsndrical, bomb-type reactor, - fitted with a ceramic liner of magnesia. The liner was covered with a magnesia lid and tho space between the liner and bomb walls filled with sand. The bomb lid was then placed in position and socurely fastened to the main body of the apparatus, using a copper gasket to make a tight soal. Next, the bomb was evacuated through a removable screw plug in the bomb lid,
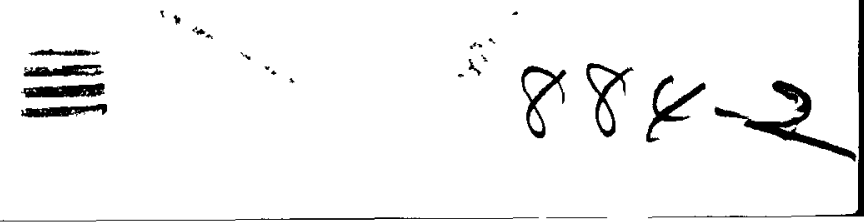
followed by the filling of the $/ / 4$ /

followed by the filling of the Haratus with argon gas, the rrocess being repeated four times to insure exclusion of air from the system. The apparatus was egain sealed, and hosted by moans of an induction furnace, the temperature being raised about $12-15^{\circ} \mathrm{C}$ per minute. At an estimated temperature of $700^{\circ} \mathrm{C}$, the occurrence of a reaction was evidenced by a sudden rise in temperature. The bomb was then conled to room temperature and opened for oxamination of the reaction products. Emall pellets of metallic uranium of the order of 0.5 - $1 \mathrm{~mm}$. diameter were found to be dispersed throughout the slag which vas formed during the reaction, with the mafor portion of the product being located at the bottom of the melt.

A second experiment was carried out with 86 grams of UF 6 as charge material along with 107 grams of calcium and 13 grams of iodine. Tho apparatus usod in this test was larger than that used in the first experiment, due to the volume required to satisfy the charge container and reactants, otherwise the two runs were carried out in like manner. In this case, reaction occurred at $330^{\circ} \mathrm{C}$ (bomb wall teinperature), as evidenced by a rapid rise in temperature. After cooling the apparatus and contents, tile bomb was opened and the contents removed. On examining the reaction products, a button of uranium, weighing approximately 42 grams, was found at the bottom of the melt, with other small pellots about $1 \mathrm{~mm}$. or less in diameter dispersed throughout the melt, with a few pellets being located on the walls of the liner and the liner lid above the melt. It should be mentionod that in this run a sudden pressure development within the bomb was belleved to have occurred, as the bomb jumped about one inch in an upward direction off of the base of the furnace when the reaction was initiated. Evidence vas found in eagh/experiment to show that a slight 